\author{
${ }^{1}$ Szkoła Gtówna Gospodarstwa Wiejskiego w Warszawie, Wydziat Rolnictwa i Biologii, \\ Katedra Nauk o Środowisku Glebowym, ul. Nowoursynowska 159, 02-776 Warszawa \\ ${ }^{2}$ Politechnika Warszawska, Wydziat Geodezji i Kartografii, Katedra Gospodarki Przestrzennej i Nauk o Środowisku \\ Przyrodniczym, Pl. Politechniki 1, 00-661 Warszawa
}

\title{
Problemy gleboznawczej klasyfikacji bonitacyjnej gruntów rolnych w zasięgu oddziaływania leja depresyjnego KWB „Bełchatów”
}

\begin{abstract}
Streszczenie: Celem przeprowadzonych badań było wskazanie najważniejszych problemów związanych z gleboznawczą klasyfikacją gruntów rolnych w rejonie Kopalni Węgla Brunatnego „Bełchatów”. Analiza polegała na porównaniu danych dla wsi Łękińsko zawartych na mapach i w operatach klasyfikacyjnych z 1959 roku (okres przed otwarciem KWB „Bełchatów”) z mapami i operatami zaktualizowanymi w 1998 roku, tj. około 20 lat po rozpoczęciu działalności przez kopalnię. Z przeprowadzonych badań wynika, że jedynie 14\% obszaru obrębu Łękińsko niezajętego przez kopalnię zostało objęte ponowną klasyfikacją gruntów. Odkrywki glebowe zostały zlokalizowane wyłącznie na terenach, których użytkowanie zmieniło się w stosunku do stanu z 1959 roku z tym, że nie wszystkie nowo wyróżnione kontury glebowe były reprezentowane przez nowe odkrywki glebowe. Liczba odkrywek w stosunku do liczby nowo wydzielonych konturów klasyfikacyjnych wydaje się być niewystarczająca. Zmiany klas bonitacyjnych po aktualizacji w 1998 roku dotyczyły tylko tych działek, na których w stosunku do roku 1959 zmieniło się użytkowanie, najczęściej z gruntów ornych na użytki zielone. W ocenie autorów, zamiana klasy gruntu ornego (np. IIIa) na analogiczną klasę użytku zielonego (np. III) stosowana w trakcie aktualizacji mapy klasyfikacyjnej nie zawsze jest prawidłowa, ze względu na zróżnicowaną rangę czynników decydujących o wyborze klasy bonitacyjnej dla gruntów ornych i użytków zielonych. Na podstawie uzyskanych wyników autorzy sugerują, aby aktualizacji map klasyfikacyjnych dla obszarów objętych silnym odwodnieniem spowodowanym np. przez działalność kopalń odkrywkowych lub głęboką meliorację, nie ograniczać tylko do działek o zmienionym użytkowaniu, a wykonywać na całym obszarze przeznaczonym do aktualizacji. Aktualizacja każdego nowego konturu klasyfikacyjnego powinna być dokonywana w oparciu o odpowiednią liczbę odkrywek glebowych położonych, w miarę możliwości, w niedalekim sąsiedztwie w stosunku do odkrywek z pierwszej mapy klasyfikacyjnej, co umożliwiłoby porównywanie ich właściwości oraz analizę zmian jakie zaszły w glebach w wyniku głębokiego odwodnienia.
\end{abstract}

Słowa kluczowe: gleboznawcza klasyfikacja gruntów, lej depresyjny, Kopalnia Węgla Brunatnego „Bełchatów”

\section{WSTĘP}

Odkrywkowa eksploatacja węgla brunatnego niesie ze sobą wiele niekorzystnych zmian w środowisku. Jednym z negatywnych skutków prac górniczych w rejonie kopalń odkrywkowych jest powstanie leja depresyjnego, którego przejawem jest obniżenie zwierciadła wód gruntowych w rejonie kopalni, co w konsekwencji powoduje osuszenie terenu. Lej depresyjny silnie oddziałuje na gospodarkę wodną gleb, co z kolei wpływa na ich klasę bonitacyjną oraz przydatność rolniczą.

Dotychczasowe badania, prowadzone w silnie przesuszonych rejonach kopalń węgla brunatnego w Polsce, skupiały się głównie wokół zagadnienia oddziaływania leja depresyjnego na właściwości gleb i ich gospodarkę wodną oraz oceny wpływu osuszenia gleb na plonowanie roślin uprawnych (m.in. Terelak i Karczewski 1977; Maciak 1987; Sapek i in. 1991; Rząsa i in. 1999; Mocek i in. 2002, 2006; Bi- skupski i in. 2008; Owczarzak i in. 2008; Pabin i in. 2008; Turbiak i Miatkowski 2008; Włodek i in. 2008; Komisarek i in. 2011; Włodek i Biskupski 2011), natomiast problem wpływu odwodnienia i przemian w środowisku glebowym na bonitację i przydatność rolniczą gleb nie był do tej pory w literaturze polskiej szerzej analizowany (m.in. Rząsa i in. 1999). Celem przeprowadzonych badań była ocena wpływu leja depresyjnego w rejonie Kopalni Węgla Brunatnego (KWB) „Bełchatów” na jakość gleb użytkowanych rolniczo (gruntów ornych oraz użytków zielonych), a także próba wskazania problemów związanych z przeprowadzeniem gleboznawczej klasyfikacji bonitacyjnej gruntów tamtego rejonu.

\section{OBSZAR I METODYKA BADAŃ}

Badaniami został objęty obręb Łękińsko (gmina Kleszczów, powiat bełchatowski, województwo łódzkie) graniczący bezpośrednio od północy z KWB 
„Bełchatów”. Odwadnianie tego obszaru rozpoczęto w 1975 roku (Terelak i Karczewski 1977; Pałac1981). Wynikiem tego było powstanie leja depresyjnego, który już w 1976 roku objął swoim zasięgiem większą część analizowanego obrębu. W 1977 roku rozpoczęto zdejmowanie nadkładu na polu „Bełchatów”, co spowodowało dewastacje powierzchni terenu oraz całkowite zniszczenie pokrywy glebowo-roślinnej. W 1998 roku 27\% powierzchni obrębu Łękińsko stanowiły tereny zdewastowane przeznaczone pod funkcje związane z działalnością kopalni (ryc. 1 i 2), natomiast jego pozostała część znajdowała się w zasięgu oddziaływania leja depresyjnego, co m.in. stanowiło podstawę do przeprowadzenia w 1998 roku aktualizacji gleboznawczej klasyfikacji gruntów.

Prezentowane opracowanie przedstawia zmiany w jakości i przydatności rolniczej gleb analizowanego obrębu na podstawie porównania wyników gleboznawczej klasyfikacji gruntów z 1959 roku (mapy klasyfikacyjnej, opisów odkrywek glebowych oraz danych z operatu klasyfikacyjnego), tj. z okresu przed otwarciem KWB „Bełchatów”, z analogicznymi materiałami zebranymi w wyniku aktualizacji gleboznawczej klasyfikacji gruntów, wykonanej w 1998 roku, tj. około 20 lat po rozpoczęciu działalności przez kopalnię. W artykule stosowano nazwy gleb używane oryginalnie $\mathrm{w}$ analizowanych opracowaniach klasyfikacyjnych. W badaniach wykorzystano oprogramowanie komputerowe ArcGIS służące do analizy informacji o przestrzeni.

\section{WYNIKI BADAŃ I DYSKUSJA}

\section{Charakterystyka przemian pokrywy glebowej i użytkowania gruntów w obrębie Łękińsko}

Pokrywa glebowa badanego obszaru jest typowa dla Niżu Polskiego. Dominują w niej gleby bielicowe, płowe i brunatne. Przed rozpoczęciem działalności KWB „Bełchatów” (Mapa klasyfikacyjna, 1959) kilkanaście procent powierzchni Łękińska pokrywały gleby bagienne (głównie torfowe i torfowo-mułowe), które występowały w północnej, północno-zachodniej i środkowej części obrębu, gdzie znajdowała się niewielka dolina (ryc. 1). W wyniku prac związanych ze zdejmowaniem nakładu pokrywa glebowa północnej część Łękińska została całkowicie zniszczona (ryc. 2). W 1998 roku, tj. po upływie około 20 lat od rozpoczęcia działalności przez KWB „Bełchatów", gleby bagienne występujące w centralnej części obrębu przekształciły się $\mathrm{w}$ gleby pobagienne (głównie mineralno-murszowe i murszowate) (ryc. 1 i 2), co jest procesem typowym dla głęboko odwodnionych gleb organicznych (m.in. Rząsa i in. 1999;
Komisarek $\mathrm{i}$ in 2011). W sąsiedztwie terenów z glebami pobagiennymi występowały niewielkie powierzchnie czarnych ziem. Pokrywa glebowa pozostałej części Łękińska nie uległa istotnym przemianom.

Gleby badanego obrębu uległy silnemu odwodnieniu, co potwierdza porównanie par odkrywek glebowych wybranych z map klasyfikacyjnych z 1959 i 1998 roku położonych w niedużej odległości od siebie (maksymalnie $165 \mathrm{~m}$ ) (tabela). W odkrywkach z 1959 roku oglejenie występowało w niektórych przypadkach już na głębokości $40 \mathrm{~cm}$. Z kolei, w żadnej z odkrywek opisanych w trakcie aktualizacji mapy klasyfikacyjnej w 1998 roku dla badanego obrębu, nie stwierdzono występowania wody gruntowej, ani nawet śladów oglejenia. W operacie klasyfikacyjnym z 1959 roku 32 odkrywki z 36 na użytkach zielonych miały gruntowo-wodny typ gospodarki wodnej. Były one rozmieszczone w różnych miejscach w obrębie Łękińsko. Świadczy to o tym, że na badanym obszarze występował wysoki poziom wód gruntowych. Natomiast w operacie klasyfikacyjnym z 1998 roku dla 32 z 38 odkrywek, dla których podano informację odnośnie typu gospodarki wodnej, był to typ opadoworetencyjny. Oznacza to, że typ gospodarki wodnej w regionie uległ przemianie w wyniku silnego odwodnienia spowodowanego występowaniem leja depresyjnego.

Z analizy mapy klasyfikacyjnej z 1959 roku oraz po ponownej klasyfikacji z 1998 roku wynika, że na analizowanym obszarze nastapił bardzo wyraźny ubytek areału gruntów ornych na rzecz użytków zielonych, przede wszystkim pastwisk (ryc. 3) (Kurbiel i in. 2012). Należy domniemywać, że na wielu działkach grunty te były przez wiele lat odłogowane, w wyniku czego porosły trawami i dlatego w trakcie aktualizacji mapy klasyfikacyjnej dla Łękińska zostały sklasyfikowane jako pastwiska. Zmiany te były, jak należy sądzić, skutkiem samodzielnej decyzji właścicieli działek.

Niewielkie obszary, które w 1959 roku były użytkami zielonymi (głównie łąkami) występującymi w obrębie torfowisk niskich, w 1998 roku zostały zamienione $\mathrm{w}$ grunty orne. Przykładem tego sa grunty reprezentowane przez pary odkrywek 4 i 143 oraz 19 i 103 (tabela), odpowiednio z 1959 i 1998 roku, występujące w centralnej części Łękińska (ryc. 3). Jest to typowy przykład transformacji użytków, wynikający ze zmiany warunków glebowo-wodnych. Analiza opisów odkrywek zawartych w operatach klasyfikacyjnych dla obu okresów badawczych pokazała, że występujące na omawianych obszarach w 1959 roku okresowo podmokłe gleby torfowe porośnięte przez trawy i turzyce przekształciły się w gleby pobagienne o prawidłowych stosunkach wodnych, na których 


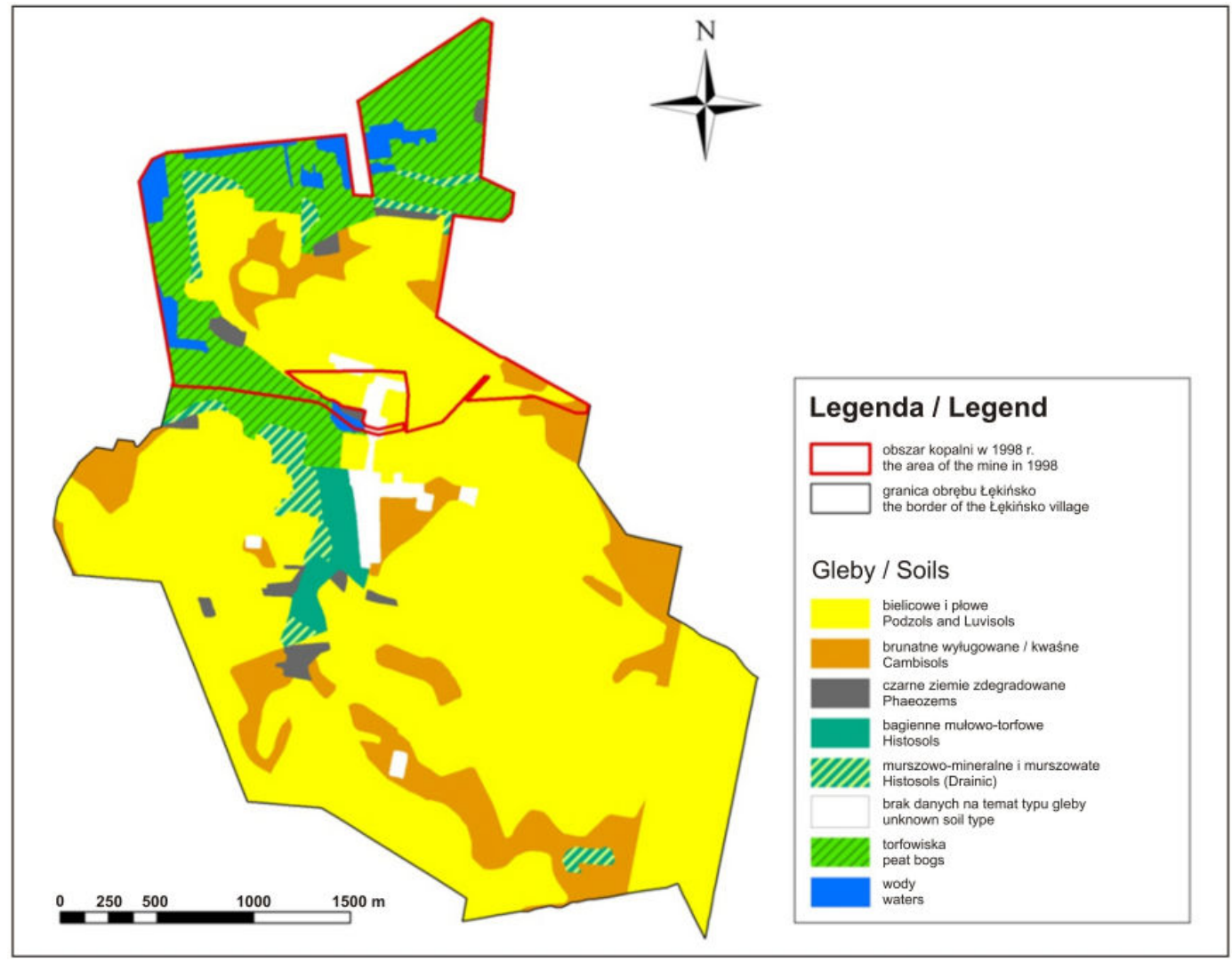

RYCINA 1.

Pokrywa glebowa obrębu Łękińsko na podstawie danych z mapy klasyfikacyjnej (1959 rok)

FIGURE 1.

Soil cover of the Łękińsko village based on the data from soil quality classification map (year 1959)

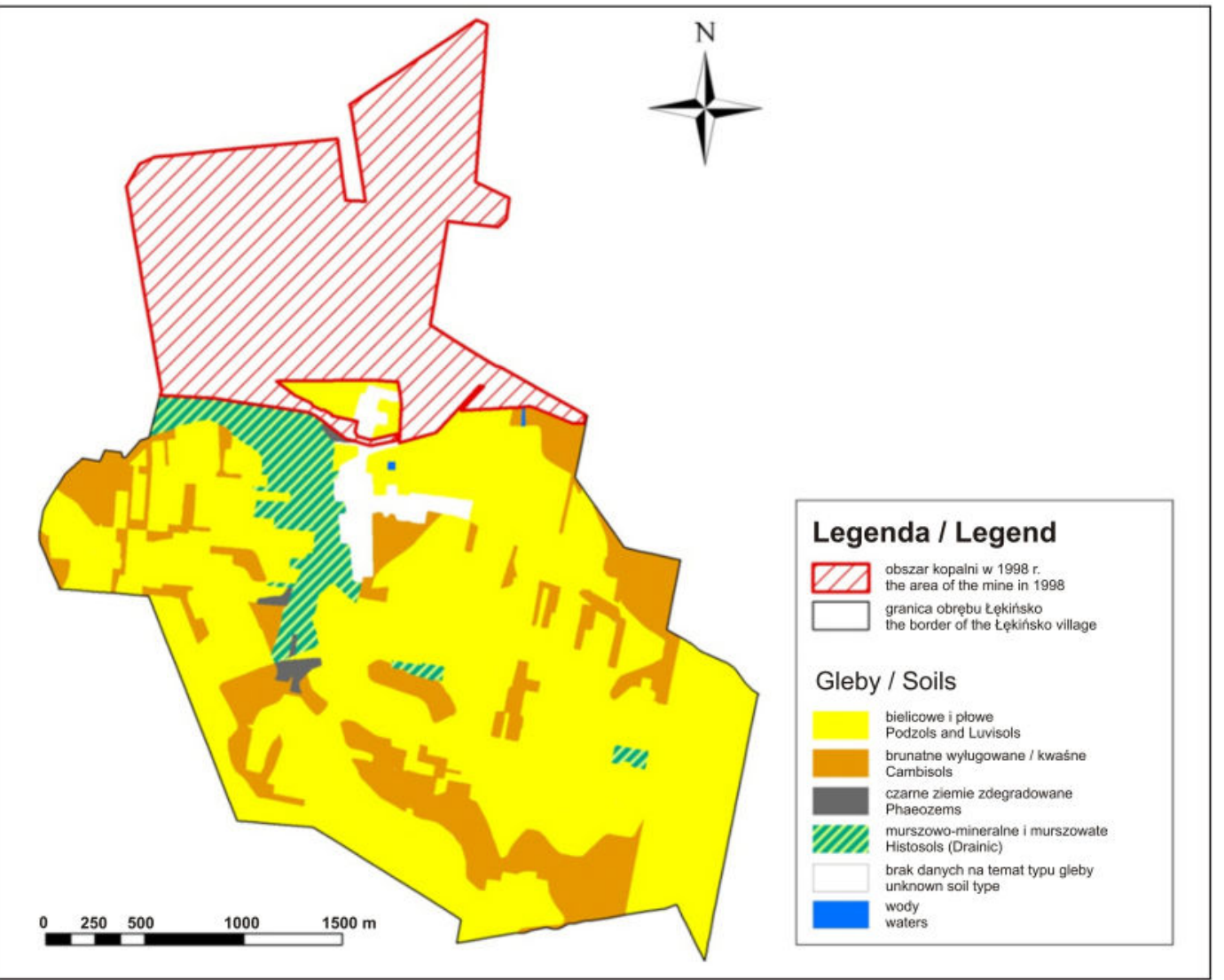

RYCINA 2.

Pokrywa glebowa obrębu Łękińsko na podstawie danych z mapy klasyfikacyjnej zaktualizowanej w 1998 roku

FIGURE 2.

Soil cover of the Łękińsko village based on the data from soil quality classification map updated in 1998 


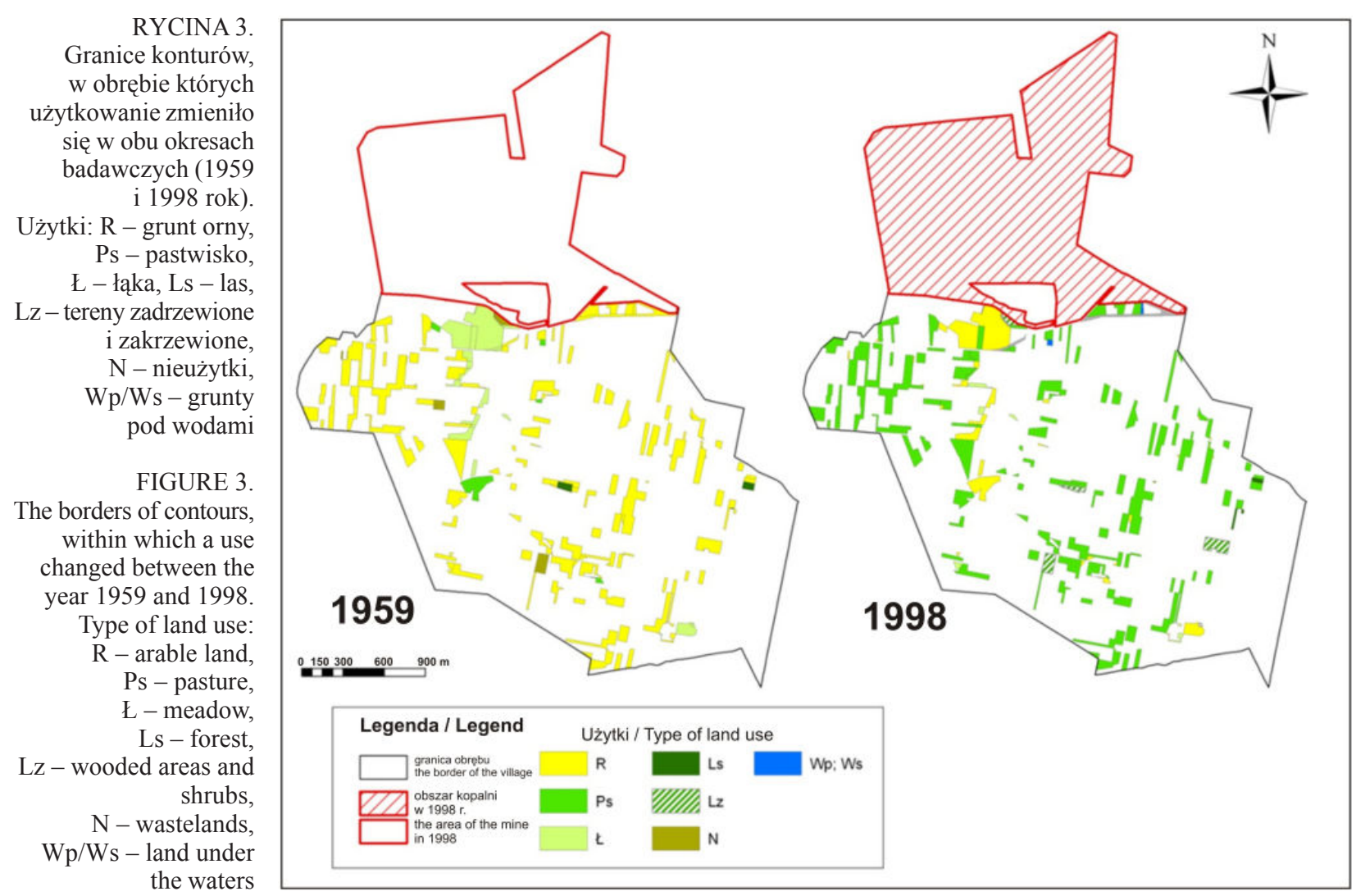

uprawiano owies, jęczmień i ziemniaki (tabela). Przyczyną zamiany użytków zielonych na grunty orne był zatem spadek wilgotności, a przede wszystkim obniżenie poziomu wód gruntowych w glebach na skutek przesuszenia wywołanego lejem depresyjnym, co w konsekwencji umożliwiło uprawę płużną na tych terenach.

\section{Problemy klasyfikacji bonitacyjnej gruntów w zasięgu występowania leja depresyjnego}

Mapa klasyfikacyjna z 1959 roku obrębu Łękińsko została opracowana na podstawie 191 odkrywek podstawowych i podobnych (Mapa klasyfikacyjna, 1959), co oznacza, że średnio 4,7 ha powierzchni przypadło na jedną odkrywkę. W północnej części obrębu, obecnie zajętej przez działalność górniczą (ryc. 1 i 2), znajdowały się 62 odkrywki, a w części południowej - 129. Były one lokalizowane głównie na gruntach ornych ( $76 \%$ wszystkich odkrywek), a w części północnej również na użytkach zielonych (35 odkrywek). Na zaktualizowanej w 1998 roku mapie klasyfikacyjnej obszaru niezajętego przez kopalnię występowało 38 odkrywek glebowych (Mapa klasyfikacyjna, 1998), a średnio na jedną odkrywkę przypadało 17,3 ha powierzchni. Zaktualizowana mapa klasyfikacyjna zawierała 132 nowe kontury klasyfikacyjne bądź kontury zmienione w stosunku do wcze- śniejszej wersji mapy (ryc. 3), zatem nie wszystkie te kontury były reprezentowane przez odkrywki glebowe wykonane w trakcie aktualizacji mapy. Wszystkie odkrywki (38) na zaktualizowanej mapie klasyfikacyjnej były zlokalizowane wyłącznie na terenach, których użytkowanie zmieniło się w stosunku do stanu z 1959 roku, głównie w obrębie pastwisk znajdujących się na dawnych gruntach ornych (ryc. 3). W przypadku aktualizacji mapy klasyfikacyjnej dla obrębu Łękińsko z 1998 roku, liczba odkrywek glebowych w stosunku do liczby nowo wydzielonych (lub zmienionych) konturów klasyfikacyjnych wydaje się być niewystarczająca.

Aktualizacja mapy klasyfikacyjnej obrębu Łękińsko dotyczyła jedynie 14\% obszaru niezajętego przez kopalnię (ryc. 3). Analiza map z porównywanych okresów wykazała, że zmiany klas bonitacyjnych po aktualizacji w 1998 roku dotyczyły tylko tych działek, na których w stosunku do roku 1959 zmieniło się użytkowanie (ryc. 4 i 5). W przypadku konturów, dla których w trakcie aktualizacji wykonano odkrywki glebowe, klasy użytków zielonych położonych na dawnych gruntach ornych zmieniały się najczęściej odpowiednio do klasy gruntów ornych, tj. klasy IIIa i IIIb gruntów ornych na III klasę użytków zielonych, IVa i IVb na IV, i podobnie w odniesieniu do pozostałych klas - V i VI (ryc. 4 i 5). Analogiczna sytuacja miała miejsce $\mathrm{w}$ przypadku gruntów ornych występu- 


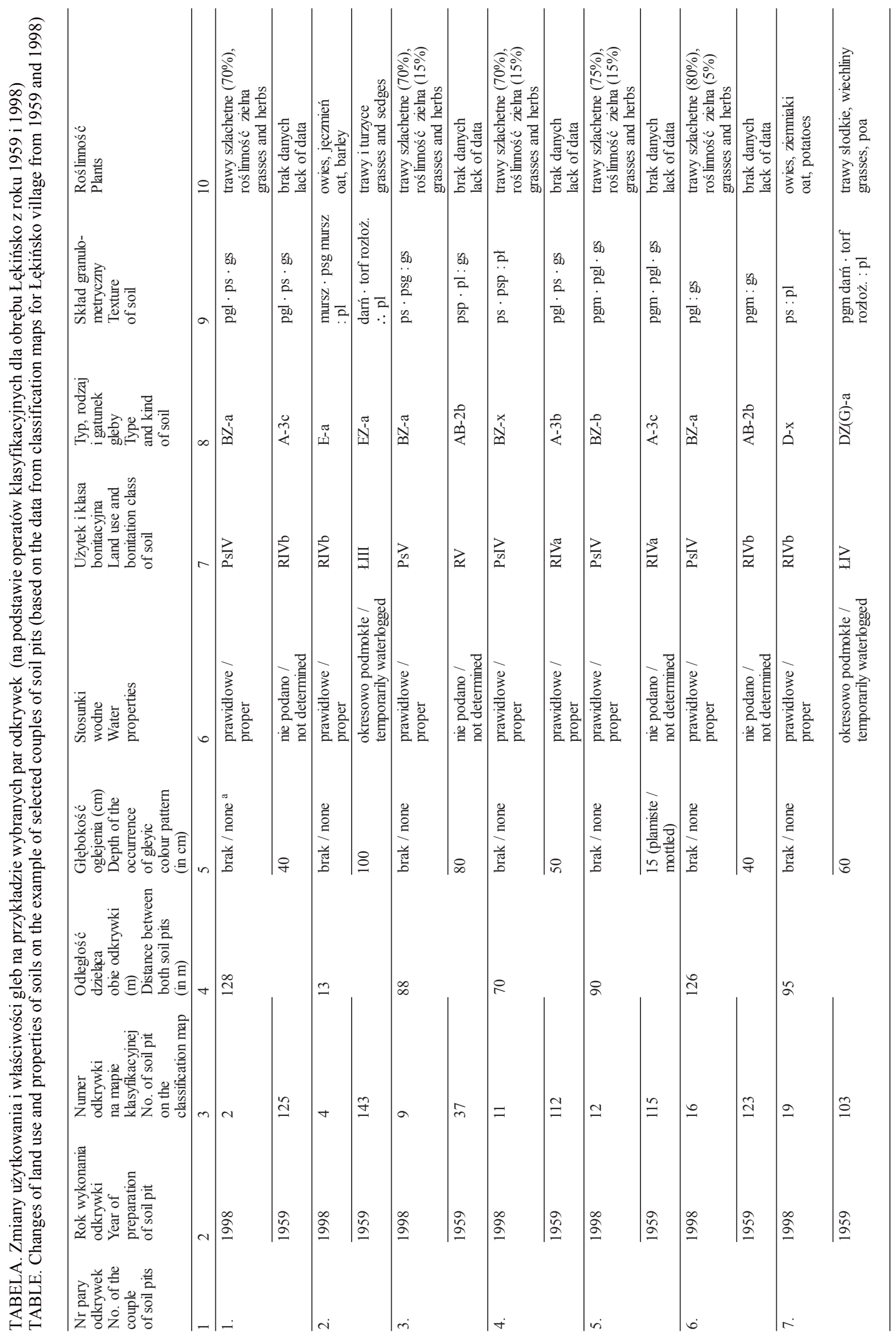




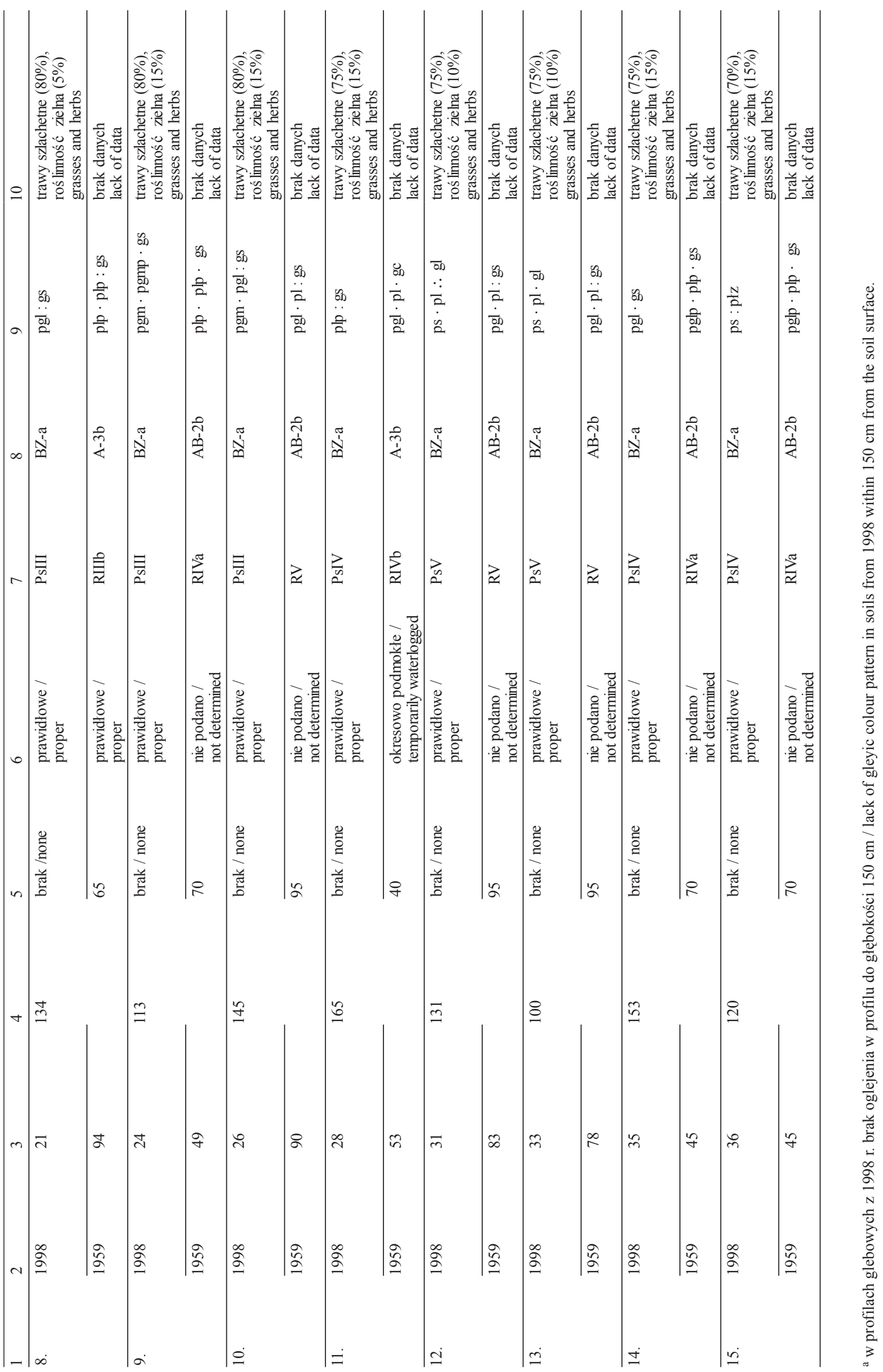



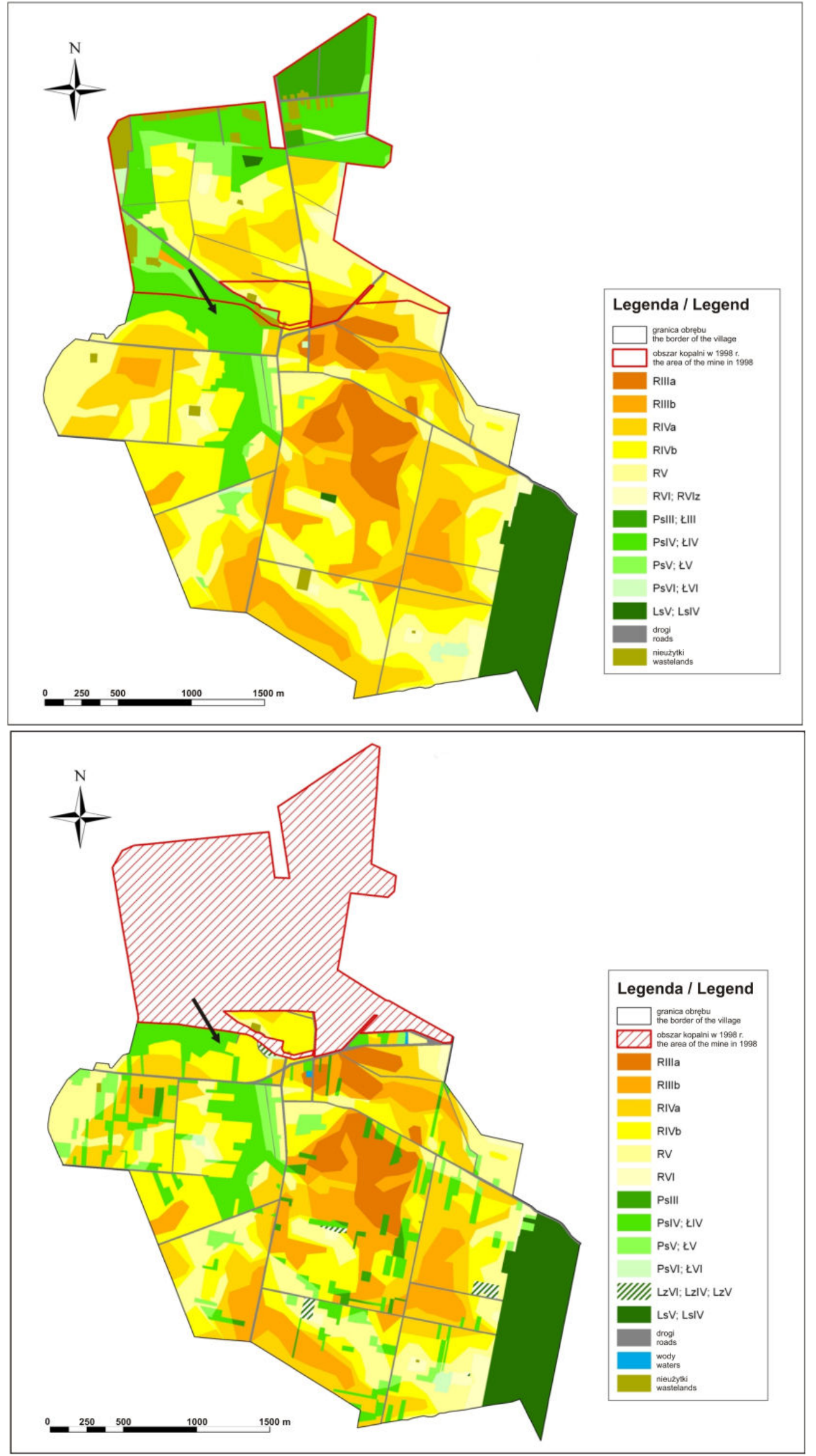

RYCINA 4.

Klasyfikacja

i bonitacja użytków

rolnych

w obrębie Łękińsko w 1959 roku.

Strzałką oznaczono

teren, na którym

zaszły największe

przekształcenia

użytków zielonych

w grunty orne

FIGURE 4

Soil quality classification

of farmlands in the

Łękińsko village

in 1959.

The arrow indicates areas where

the transformations of permanent pastures into arable lands were the most evident

\section{RYCINA 5.}

Klasyfikacja i bonitacja użytków rolnych w obrębie Łękińsko w 1998 roku. Strzałką oznaczono teren, na którym zaszły największe przekształcenia użytków zielonych $\mathrm{w}$ grunty orne

FIGURE 5.

Soil quality

classification of farmlands in the Łekińsko village in 1998. The arrow indicates areas where the transformations of permanent pastures into arable lands were the most evident 
jących w 1998 roku na dawnych użytkach zielonych, czego przykładem jest teren z centralnej części Łękińska, gdzie użytki zielone klasy IV zostały zaklasyfikowane do klasy IVb gruntów ornych (ryc. 4 i 5). Z analizy obu map wynika, że na pozostałym obszarze, nieobjętym klasyfikacją ( $86 \%$ powierzchni obrębu niezajętej przez kopalnię) rozmieszczenie użytków gruntowych oraz ich bonitacja pozostały bez zmian.

Nowo wydzielone w 1998 roku kontury klasyfikacyjne użytków zielonych nieposiadające odkrywek glebowych, zostały zaliczone przeważnie odpowiednio do analogicznej klasy gruntów ornych na tym obszarze (np. w przypadku klas bonitacyjnych IIIa i IIIb gruntów ornych przydzielano klasę III użytków zielonych itd.), co nie zawsze jest prawidłowe ze względu na zróżnicowaną rangę czynników decydujących o wyborze klasy bonitacyjnej dla gruntów ornych i użytków zielonych. W przypadku gruntów ornych o prawidłowych stosunkach wodnych, ich wartość produkcyjna zależy przede wszystkim od rodzaju i gatunku gleby, natomiast w przypadku użytków zielonych na wysokość plonów w dużym stopniu wpływa, obok wymienionych cech, również poziom wód gruntowych (Skłodowski i Bielska 2009). Wyniki uzyskane w trakcie analiz wskazują zatem, że dobrym rozwiązaniem byłoby klasyfikowanie użytków zielonych oraz porośniętych roślinnością łąkową odłogów na osobnych zasadach, co jednak wymagałoby wprowadzenia zmian do tabeli klas gruntów (Rozporząqzenie Rady Ministrów z dnia 12 września 2012 r.). Pozwoliłoby to na ustalenie jasnych kryteriów klasyfikacji i bonitacji obu typów użytków oraz uniknięcie problemów z ich gleboznawczą klasyfikacją.

Kolejnym zagadnieniem wynikającym z przeprowadzonych analiz jest sposób postępowania $\mathrm{z}$ terenami, na których przed rozpoczęciem odwodnienia występowały gleby o opadowo-retencyjnym typie gospodarki wodnej. W przypadku Łękińska, gdzie poziom wód gruntowych obniżył się znacznie, zasięg poszczególnych konturów klasyfikacyjnych (w tym konturów gruntów ornych wykształconych na glebach o prawidłowych stosunkach wodnych w obu okresach badawczych) mógł ulec zmianie. Autorzy sugerują, aby aktualizacja użytków i klas bonitacyjnych obejmowała cały obszar będący w zasięgu oddziaływania leja depresyjnego, a nie tylko kontury gruntów, w których zmieniło się użytkowanie.

W niektórych przypadkach, wydzielone w 1998 roku nowe kontury użytków zielonych charakteryzujące się wydłużonymi kształtami, przechodziły przez kilka starych (1959 rok) konturów gruntów ornych, wcześniej zaliczanych do różnych klas bonitacyjnych (ryc. 4 i 5). Klasa tak wyznaczonego konturu była ustalana na podstawie jednej, niekiedy dwóch odkry- wek glebowych wykonanych pośrodku tego konturu. Odległości klasyfikowanych terenów do odkrywek opisujących dany kontur, w niektórych przypadkach dochodzily do $400 \mathrm{~m}$. Na tej podstawie można wnioskować o znacznej generalizacji wykonanej aktualizacji mapy klasyfikacyjnej dla Łękińska.

Aktualizacja mapy klasyfikacyjnej przeprowadzona w powyżej opisany sposób byłaby zapewne wystarczająca na obszarze, na którym nie wystąiły nagłe znaczne zmiany w środowisku, związane przede wszystkim z silnym przekształceniem stosunków wodnych. Jednakże na terenach objętych wpływem leja depresyjnego, których przykładem jest obręb Łękińsko, zmiany te były na tyle silne, że oddziaływały w mniejszym lub większym stopniu na właściwości i bonitację wszystkich występujących tam gleb. Ważne byłoby, aby przed przystapieniem do prac klasyfikacyjnych na obszarze objętym kopalnianym odwodnieniem terenu dokonać inwentaryzacji występujących gleb pod względem typów gospodarki wodnej, na co wskazują Rząsa i in. (1999). Na podstawie zgromadzonego materiału oraz uzyskanych wyników autorzy sugerują, aby aktualizacji map klasyfikacyjnych dla obszarów objętych lejem depresyjnym nie ograniczać tylko do działek o zmienionym użytkowaniu, a wykonywać na całym obszarze przeznaczonym do aktualizacji.

\section{WNIOSKI}

1. Przed przystapieniem do prac klasyfikacyjnych na obszarze objętym kopalnianym odwodnieniem terenu należy dokonać inwentaryzacji występujących gleb pod względem typów gospodarki wodnej lub skorzystać z wcześniej wykonanych opracowań i ekspertyz, o ile takie zostały wykonane.

2. W obszarach znajdujących się w zasięgu oddziaływania leja depresyjnego zalecana jest całościowa aktualizacja użytków i klas bonitacyjnych obejmująca nie tylko kontury klasyfikacyjne, w których zmieniło się użytkowanie, ale także wszystkie pozostałe obszary w określonym obrębie, o ile taką konieczność potwierdzi wykonana wcześniej inwentaryzacja gleb pod względem typów gospodarki wodnej.

3. Aktualizacja każdego nowego konturu klasyfikacyjnego powinna być dokonywana w oparciu o reprezentatywną liczbę odkrywek glebowych położonych, w miarę możliwości w niedalekim sąsiedztwie w stosunku do odkrywek z pierwszej mapy klasyfikacyjnej, co umożliwiłoby porównywanie ich właściwości oraz analizę przemian, jakie za- 
szły w glebach w wyniku głębokiego odwodnienia.

4. W trakcie aktualizacji, szczególną uwagę należy zwracać na rejony występowania gleb hydrogenicznych i semihydrogenicznych. Gleby te bowiem najsilniej reagują na zmiany wywołane obniżeniem się zwierciadła wód gruntowych, co przekłada się na ich właściwości, bonitację i przydatność rolnicza.

5. W aktualizacji map klasyfikacyjnych omawianego obszaru, jak również w określaniu przydatności rolniczej gleb na tych terenach należy brać pod uwagę możliwość występowania przypadków gleb nieopisanych w Urzędowej tabeli klas (Rozporządzenie Rady Ministrów z dnia 12 września 2012 r.) oraz „Wykazie gatunków i odmian gleb według komentarza do tabeli klas i kompleksów przydatności rolniczej". Ocena taka wówczas powinna być zbliżona do opisu występującego w urzędowej tabeli klas wraz z odpowiednim komentarzem.

\section{LITERATURA}

Biskupski A., Włodek S., Pabin J., 2008. Dynamika uwilgotnienia gleby w zasięgu leja depresji kopalni odkrywkowej węgla brunatnego-Bełchatów. Roczniki Gleboznawcze-Soil Science Annual, 59(2): 18-24.

Komisarek J., Matczak S., Pawłowski M., 2011. Zróżnicowanie przestrzenne gleb organicznych wokół odkrywki „Jóźwin IIB” KWB Konin. Roczniki Gleboznawcze - Soil Science Annual, 62(2): 212-218.

Kurbiel M., Uzarowicz Ł., Maciejewska A., 2012. Wpływ kopalnictwa odkrywkowego na gospodarowanie przestrzenią rolniczą w rejonie KWB „Bełchatów”. Studia KPZK PAN, 142: 351-355.

Maciak F., 1987. Produktywność i podatność na mineralizację gleb torfowych rejonu leja depresyjnego „Bełchatów”. Roczniki Gleboznawcze - Soil Science Annual, 38(4): 71-93.

Mapa klasyfikacyjna, 1959. Obręb Łękińsko, gmina Kleszczów. Operat klasyfikacyjny nr 221/7/85/62. Starostwo Powiatowe w Bełchatowie.

Mapa klasyfikacyjna, 1998. Obręb Łękińsko, gmina Kleszczów. Operat klasyfikacyjny zmienionych użytków nr 573.12-24/99. Starostwo Powiatowe w Bełchatowie.

Mocek A., Owczarzak W., Gajewski P., 2006. Degradacja użytków rolnych doliny Noteci w sąsiedztwie odkrywki węgla brunatnego „Lubstów”. Roczniki Gleboznawcze - Soil Science Annual, 57(1/2): 138-151.
Mocek A., Owczarzak W., Kaczmarek Z., 2002. Zmiany zalegania zwierciadła wód gruntowych w glebach otaczających wyrobisko węgla brunatnego „Koźmin”. Roczniki AR w Poznaniu, Melioracje i Inżynieria Środowiska, 342(23): 331-342.

Owczarzak W., Mocek A., Kaczmarek Z., Gajewski P., 2008. Ocena stopnia degradacji naturalnej i antropogenicznej gleb w obszarze odwadniającego oddziaływania odkrywki węgla brunatnego Drzewce. Roczniki Gleboznawcze - Soil Science Annual, 59(2): 177-190.

Pabin J., Włodek S., Biskupski A., 2008. Oddziaływanie głębokiego odwodnienia odkrywki KWB Bełchatów na uwilgotnienie gleby. Roczniki Gleboznawcze - Soil Science Annual, 59(2): 191-195.

Pałac T., 1981. Rys historyczny Kopalni Węgla Brunatnego „Bełchatów" w aspekcie realizacji robót odwodnienia wgłębnego. Materiały na konferencję naukowo-techniczną pt. „Wpływ budowy Kopalni Węgla Brunatnego „Bełchatów” na środowisko przyrodnicze". Naczelna Organizacja Techniczna Stowarzyszenie Inżynierów i Techników Wodnych i Melioracyjnych, Łódź, czerwiec $1981 \mathrm{r}$.

Rozporządzenie Rady Ministrów z dnia 12 września 2012 r. w sprawie gleboznawczej klasyfikacji gruntów (Dz.U. z 2012, poz. 1246).

Rząsa S., Owczarzak W., Mocek A., 1999. Problemy odwodnieniowej degradacji gleb uprawnych w rejonach kopalnictwa odkrywkowego na Niżu Środkowopolskim. Wydawnictwo Akademii Rolniczej im. Augusta Cieszkowskiego w Poznaniu: $394 \mathrm{~s}$.

Sapek A., Sapek B., Gawlik J., 1991. Rozpoznanie nasilenia mineralizacji azotu w glebach torfowych w zasiegu leja depresyjnego kopalni Bełchatów. Wiadomości IMUZ, 16(3): 79-86.

Skłodowski P., Bielska A., 2009. Potrzeby i metody aktualizacji gleboznawczej klasyfikacji gruntów. Uczelnia Warszawska im. Marii Skłodowskiej-Curie. Instytut Geodezji i Kartografii, Warszawa.

Terelak H., Karczewski A., 1977. Głębokość występowania i skład chemiczny wód glebowo-gruntowych w rejonie Kombinatu Górniczo-Energetycznego Bełchatów. Roczniki Gleboznawcze - Soil Science Annual, 28(1): 3-14.

Turbiak J., Miatkowski Z., 2008. Ocena tempa mineralizacji organicznych związków azotu w głęboko odwodnionych glebach torfowo-murszowych. Roczniki Gleboznawcze - Soil Science Annual, 59(3/4): 276-283.

Włodek S., Biskupski A., 2011. Dynamika wilgotności gleby w rejonie Kopalni Węgla Brunatnego Bełchatów. Roczniki Gleboznawcze - Soil Science Annual, 62(2): 420-427.

Włodek S., Biskupski A., Pabin J., 2008. Wilgotność gleby w rejonie odkrywkowej kopalni węgla brunatnego Bełchatów. Roczniki Gleboznawcze - Soil Science Annual, 59(2): 230-235.

Received: January 12, 2015

Accepted: February 18, 2015 


\title{
Problems with the soil classification and quality assessment of agricultural lands in the range of cone of depression around the "Bełchatów" open pit lignite mine (Poland)
}

\begin{abstract}
The aim of the study was to identify the main problems related to the soil classification and quality assessment of agricultural land in the area of the "Bełchatów" lignite mine. The analysis was based on a comparison of data for the Łękińsko village (Kleszczów municipality, Łódź Province, middle Poland) included in the classification map and data from 1959 (the period before the opening of the "Bełchatów" lignite mine) with the map and data updated in 1998, i.e. about 20 years after the opening the mine. Studies have shown that the update of the classification map in 1998 involved only 14\% of the area not occupied by the mine. Soil pits were located only in areas which use has changed in comparison with the year 1959. However, not every newly distinguished soil contour was represented by new soil pits. The number of pits in relation to the number of newly distinguished soil contours seems to be insufficient. Changes in quality (bonitation) classes after update in 1998 concerned only those plots where the use has changed in relation to 1959. The most common form of change was the replacement of the use of arable land into grassland. Conversion of arable land quality class (e.g. IIIa) on a similar class of grassland (e.g. III) used in the process of updating the classification maps is not always correct, because of the diverse rank of the factors determining the choice of the quality class for arable land and grassland. Based on these results obtained, the authors suggest that the updates of classification map for the areas affected by the strong dehydration resulting e.g. from the activity of open pit mines or deep drainage due to melioration, should not be limited to the plots of the changed use only, but should be perform all over the area to be updated. The update of every new soil contour should be made on the basis of an adequate number of soil pits located, when possible, in close vicinity of the pits from the first classification map. Such an approach would allow to compare the properties of soils and analyze the changes that have occurred in soils as a result of deep drainage.
\end{abstract}

Key words: soil classification (bonitation), cone of depression, the "Bełchatów" lignite mine 